\title{
IDENTIFIKASI DAN DISTRIBUSI JENIS LABI-LABI (FAMILI: TRIONYCHIDAE) DI SUMATERA SELATAN
}

\author{
Dian Oktaviani'), Noviar Andayani'2), Mirza Dikari Kusrini ${ }^{3)}$, dan Duto Nugroho ${ }^{4)}$ \\ 1) Peneliti pada Pusat Riset Perikanan Tangkap, Ancol-Jakarta \\ 2) Pengajar pada Fakultas MIPA, Universitas Indonesia, Depok \\ 3) Pengajar pada Fakultas Kehutanan, Institut Pertanian Bogor, Bogor \\ 4) Peneliti pada Balai Riset Perikanan Laut, Muara Baru-Jakarta
}

Teregristrasi I tanggal: 9 Januari 2008; Diterima setelah perbaikan tanggal: 4 April 2008;

Disetujui terbit tanggal: 14 April 2008

\begin{abstract}
ABSTRAK
Labi-labi (Testudines; Trionychidae) merupakan kelompok kura-kura air tawar. Sumatera Selatan sebagai salah satu daerah yang mempunyai potensi sumber daya ikan yang secara nyata berkontribusi dalam mengeksploitasi labi-labi di Indonesia. Penelitian ini dilakukan secara intensif dan regular pada periode bulan Pebruari 2006 sampai dengan Pebruari 2007 yang berlokasi di Sumatera Selatan. Tujuan penelitian ini adalah untuk mengidentifikasi jenis Trionychidae dan menggambarkan distribusi di Sumatera Selatan. Metode yang digunakan adalah survei lapang dan wawancara dengan penampung lokal di Palembang, Sumatera Selatan. Hasil penelitian mengindikasikan bahwa terdapat 3 jenis Trionychidae yang ada di Sumatera Selatan, yaitu Amyda cartilaginea Boddaert 1770, Dogania subplana Geoffroy 1809, dan Pelochelys cantorii Gray 1864. Jenis yang mendominasi dalam hal jumlah adalah $A$. cartilaginea $(84,28 \%)$ serta sekaligus sebagai jenis yang distribusi paling luas.
\end{abstract}

KATAKUNCI: Trionychidae, identifikasi, distribusi, Sumatera Selatan

ABSTRACT: Identification and distribution of softshell turtles (family: Trionychidae) in South Sumatera. By: Dian Oktaviani, Noviar Andayani, Mirza Dikari Kusrini, and Duto Nugroho

\begin{abstract}
Softshell turtles (Testudines; Trionychidae), known locally as labi-labi is the group of freshwater turtles. As one of the potential area of inland water fishery resources, South Sumatera plays an significant role in terms of their abundance and contribution as well to softshell turtles exploitation in Indonesia. To support the long term management technique for one of the threathened species, a one year intensive and regular observations were made during the period between February 2006 to February 2007. The study was carried out through field measurement survey and interview with the local collectors at Palembang. The aim of the study was to describe the Trionychidae species and its geographical distribution in South Sumatera. The results indicated that there were 3 species of Trionychidae occured at South Sumatera consist of Amyda cartilaginea Boddaert 1770, Dogania subplana Geoffroy 1809, and Pelochelys cantorii Gray 1864. The predominant species in volume was A. cartilaginea (84.28\%) and so was its distribution.
\end{abstract}

\section{KEYWORDS: Trionychidae, identification, distribution, South Sumatera}

\section{PENDAHULUAN}

Labi-labi atau softshell turtle (Testudines; Trionychidae) merupakan kelompok kura-kura air tawar yang banyak ditemukan di perairan air tawar seperti sungai dan rawa di daerah tropis dan subtropis (Pough et al., 2004). Ciri khas Trionychidae yaitu memiliki bagian karapas yang lunak serta ditutupi jaringan kulit lembut (Pitchard, 1979; Pough et al., 2004). Trionychidae terdiri atas 2 subfamili yaitu Trionychinae yang mencakup 11 genus dengan 21 spesies, dan Cyclanorbinae yang mencakup 3 genus dengan 6 spesies (Pough et al., 2004).
Indonesia merupakan salah satu daerah distribusi Trionychidae yang meliputi Sumatera, Kalimantan, Jawa, dan Irian (Ernst \& Barbour 1987; van Dijk, 2000; Pough et al., 2004). Ada 5 spesies Trionychidae yang dapat ditemukan di Indonesia, yaitu labi-labi bintang (Chitra chitra), labi-labi hutan (Dogania subplana), labilabi irian (Pelochelys bibroni), antipa (Pelochelys cantorii), dan bulus atau labi-labi (Amyda cartilaginea) (Riyanto \& Mumpuni, 2003).

Pemanfaatan Trionychidae di Indonesia sudah berlangsung lama. Statistik perikanan telah mencatat kura-kura air tawar sebagai salah satu komoditas

Kosrespondensi penulis: 
perikanan sejak tahun 1990-an (Oktaviani et al., 2006). Sumatera Selatan merupakan salah satu propinsi yang menghasilkan dan memanfaatkan kurakura air tawar termasuk di dalam Trionychidae. Tercatat selama kurun waktu 16 tahun (tahun 1990 sampai dengan 2005) Sumatera Selatan telah menghasilkan kura-kura air tawar 77 ton, dengan ratarata 4,8 ton per tahun.

Propinsi Sumatera Selatan (1-4 LS dan 102,25$\left.108,41^{\circ} \mathrm{BT}\right)$ meliputi 10 kabupaten dan 4 kota dengan luas 9.154.257 ha (Badan Pemerintah Daerah Sumatera Selatan, 2005). Topografi secara umum, datar dengan ketinggian 8 sampai dengan $289 \mathrm{~m}$ dpl. Propinsi tersebut dilalui oleh banyak sungai besar dan kecil serta rawa yang terstruktur dalam daerah aliran sungai yang luas 8.517.703,87 ha (Badan Pemerintah Daerah Aliran Sungai Musi 2007, data tidak dipublikasi).
Mengingat pemanfaatan Trionychidae yang tinggi sementara informasi sangat sedikit dan belum terdokumentasi, maka penelitian ini dilakukan untuk mengetahui jenis dan distribusi Trionychidae di Sumatera Selatan. Tujuan khusus dari penelitian adalah untuk mendeskripsikan jenis serta memetakan distribusi Trionychidae di Sumatera Selatan.

Metode yang diterapkan dalam penelitian adalah wawancara dengan para penampung yang ada di Palembang. Data harian tentang jenis, jumlah individu setiap jenis, serta pengukuran morfometrik dilakukan oleh seorang enumerator yang telah dilatih untuk mengumpulkan informasi tersebut. Hasil penelitian diharapkan dapat memperkaya informasi ilmiah tentang jenis dan distribusi labi-labi untuk mendukung pengelolaan.

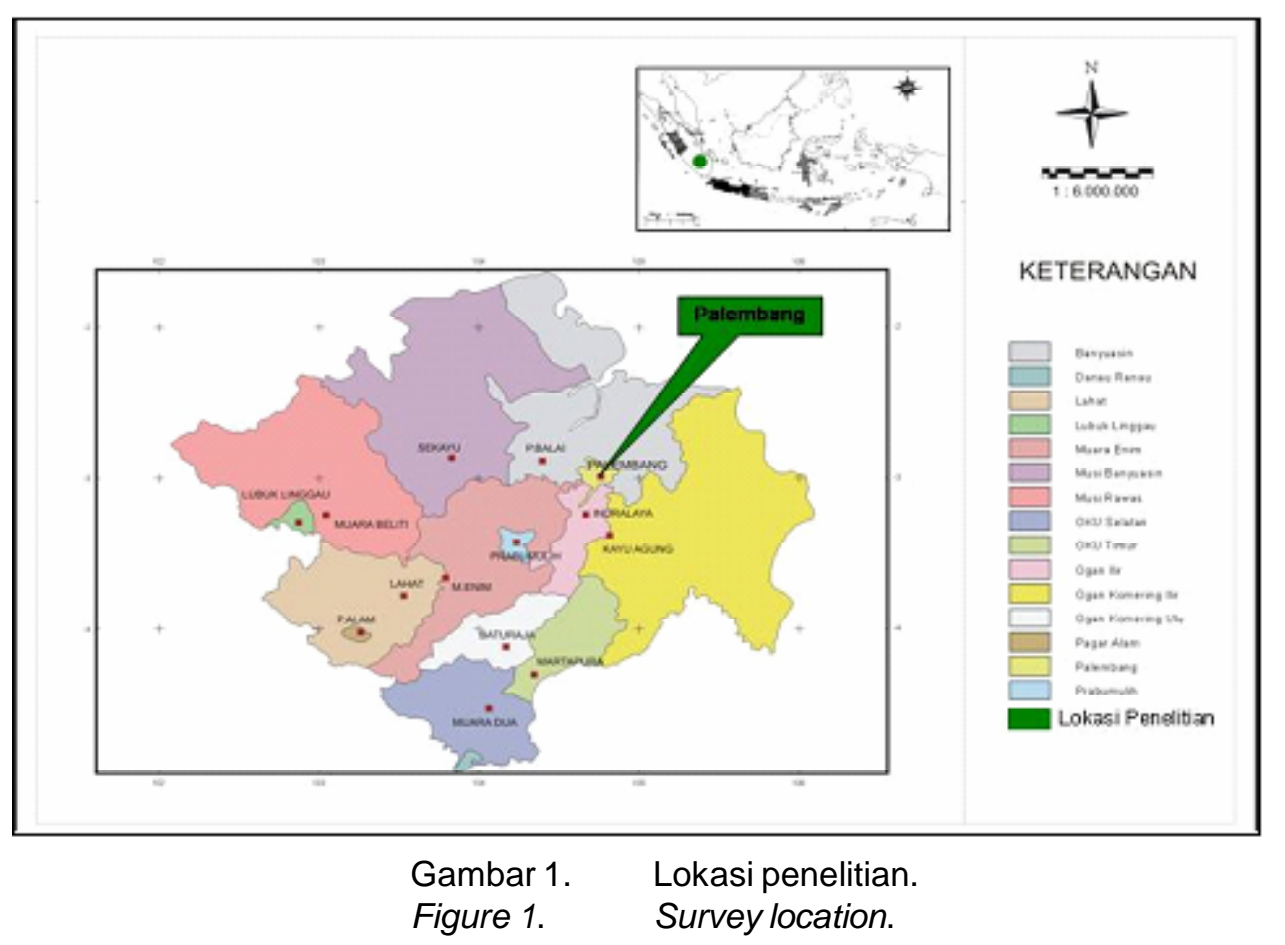

\section{BAHAN DAN METODE}

\section{Lokasi dan Waktu Penelitian}

Penelitian dilakukan di Sumatera Selatan dengan memilih Kotamadya Palembang (Gambar 1) sebagai lokasi utama untuk pengumpulan data biologi (jenis, morfometrik, dan distribusi jenis). Pelaksanaan penelitian diawali dengan survei pendahuluan pada kurun waktu pertengahan tahun 2005 untuk menentukan lokasi penelitian. Penelitian secara intensif dilakukan pada bulan Pebruari 2006 sampai dengan Pebruari 2007.

\section{Pengumpulan Data}

Obyek penelitian adalah Trionychidae, baik yang ditemukan di lapangan maupun yang terdapat di penampung. Pengumpulan data jenis dilakukan dengan mengidentifikasi kura-kura air tawar yang terdapat di penampung dan wawancara dengan penampung serta masyarakat lokal di Palembang dan 
Ogan Komering Ilir. Data biologi berupa jenis dan morfometri dilakukan di tempat penampung.

\section{Identifikasi Jenis}

Identifikasi dilakukan dengan mengacu pada Ernst \& Barbour, 1987; Iskandar, 2000; Stuart et al., 2001, dan spesimen di Museum Zoologicum Bogoriense Lembaga llmu Pengetahuan Indonesia di Cibinong. Salah satu pendekatan identifikasi yang juga dilakukan adalah wawancara pada masyarakat dengan menunjukkan foto beberapa jenis labi-labi (Testudines) dan mencatat nama lokal.

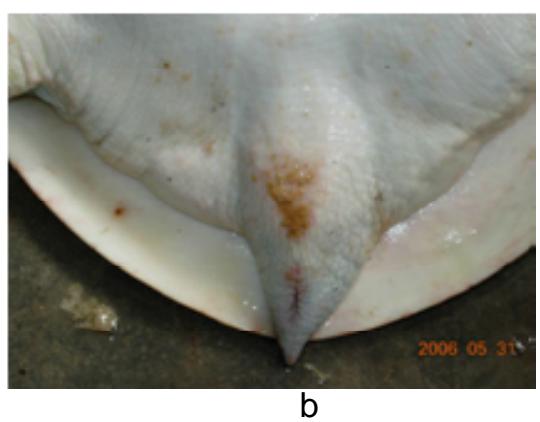

Gambar 2. a. bentuk ekor pada betina dan b. bentuk ekor pada jantan.

Figure 2. a. the tail of female and $b$. the tail of male.

Identifikasi jenis kelamin dilakukan dengan melihat bentuk ekor (Gambar 2). Perbedaan bentuk ekor berlaku untuk semua jenis labi-labi. Perbedaan jenis kelamin tersebut terlihat jelas pada ukuran panjang lengkung karapas lebih dari $25 \mathrm{~cm}$, sehingga yang berukuran kurang dari $25 \mathrm{~cm}$ dikelompokkan sebagai labi-labi muda. Labi-labi yang berukuran lebih dari $25 \mathrm{~cm}$ dibedakan berdasarkan pada jenis kelamin berupa jantan dan betina.

\section{Morfometrik}

Variabel morfometrik yang diukur adalah panjang lengkung karapas, lebar lengkung karapas, dan bobot. Pengukuran panjang lengkung dan lebar lengkung karapas labi-labi menggunakan alat pengukur berupa meteran gulung Rong Shen L-101 yang sebelumnya dilakukan kalibrasi dengan menggunakan Tricle Brand Vernier Caliper $300 \times 0,05 \mathrm{~mm}$. Kalibrasi alat pengukuran dilakukan untuk memastikan alat tersebut memenuhi standar alat ukur. Bobot badan diukur menggunakan timbangan digital Nagata tipe CYT-201W (Cap. 100 kg; Grad. 20 g). Cara dan variabel pengukuran diadopsi dari Harless \& Morlock (1979); van Heezik et al., 1994; Stuart et al., 2001. Panjang lengkung karapas diukur mulai anterior sampai dengan posterior bagian tengah karapas sedangkan lebar lengkung karapas diukur dari kiri ke kanan pada bagian tengah karapas (Gambar 2).
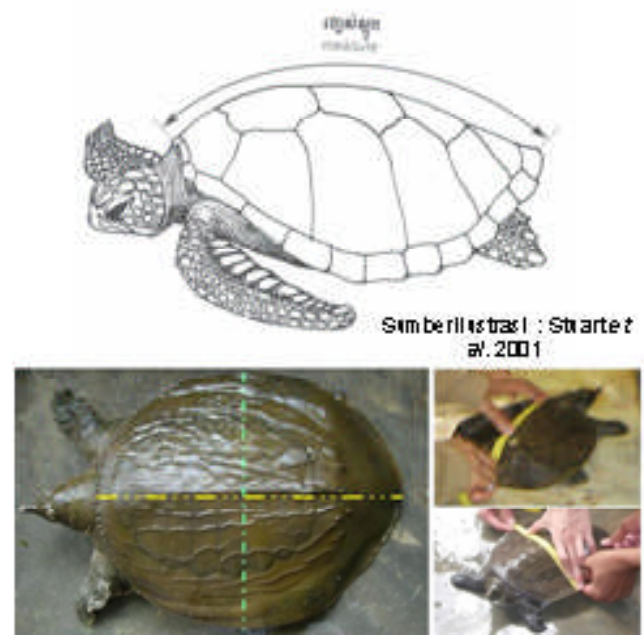

Gambar 3. Cara pengukuran panjang lengkung karapas dan lebar lengkung karapas.

Figure 3. Measument methods of curve median carapace for length and width. 
Pengukuran dilakukan oleh peneliti dan enumerator. Enumerator adalah orang yang membantu untuk mencatat data harian di penampungan dan telah dilatih untuk dapat mengisi log book. Enumerator dipilih dari 1 tempat penampungan yang bersedia untuk mengisi log book secara rutin (Lampiran 1). Pengisian log book dimonitor oleh peneliti setiap kali kunjungan. Selama kurun waktu penelitian kunjungan dilakukan 8 kali.

Enumerator mencatat jenis, panjang lengkung karapas, lebar lengkung karapas, bobot, jenis kelamin, dan daerah asal tangkapan dengan mengisi log book (Lampiran 2). Data mengenai daerah asal tangkapan diambil untuk mengetahui distribusi dari masingmasing jenis.

\section{Analisis Data}

Data ditabulasi dalam program spreadsheetseperti Microsoft Excel dan SPSS versi 12 lalu dilakukan analisis statistika sesuai dengan kebutuhan. Pemetaan menggunakan program Map-Info dan Surfer.
Hasil analisis data disajikan secara deskripsi (seperti grafik, foto, dan peta).

Data morfometrik yang diperoleh ditelaah dengan statistik deskriptif yang meliputi rata-rata $(\bar{X})$, simpangan baku (STD), dan kesalahan baku (SE). Dimorfisme antar jenis kelamin, perbedaan antara spesies dilakukan uji t (ttest) yang sebelumnya data tersebut dipastikan berdistribusi normal dengan uji normalitas.

\section{HASIL DAN BAHASAN}

\section{Keanekaragaman Jenis dan Distribusi Labi-labi di Sumatera Selatan}

Hasil identifikasi yang dilakukan di tempat penampungan labi-labi di Palembang, diketahui terdapat 3 jenis labi-labi dari famili Trionychidae yaitu Amyda cartilaginea Boddaert 1770, Dogania subplana Geoffroy 1809, dan Pelochelys cantorii Gray 1864 (Tabel 1).

Tabel $1 \quad$ Jenis labi-labi dari famili Trionychidae di Sumatera Selatan

Table 1. Species of softshell turtles (Trionychidae) in South Sumatera

\begin{tabular}{|c|c|c|c|c|}
\hline No. & $\begin{array}{l}\text { Nama lokali } \\
\text { Locai names }\end{array}$ & $\begin{array}{l}\text { Nama Indonesia*il } \\
\text { indonesian names }\end{array}$ & $\begin{array}{l}\left.\text { Nama Inggris }{ }^{\star}\right) \\
\text { Engish names }\end{array}$ & $\begin{array}{l}\text { Nama Ilmiah }{ }^{\star} \text { li } \\
\text { Scientinc names }\end{array}$ \\
\hline 1. & Labi-labi super & Labi-labi atau bulus & Asiatic softshell turtie & $\begin{array}{l}\text { Amyda cartilaginea Boddaert } \\
1770\end{array}$ \\
\hline 2. & $\begin{array}{l}\text { Labi-labi batu atau labi- } \\
\text { labi cump }\end{array}$ & Labi-labi hutan & Malayan softshell turtie & $\begin{array}{l}\text { Dogania subplana Geoffroy } \\
1809\end{array}$ \\
\hline 3. & Bidari & $\begin{array}{l}\text { Labi-labi raksasa atau } \\
\text { antipa }\end{array}$ & $\begin{array}{l}\text { Cantor's giant softshell } \\
\text { turtie }\end{array}$ & Pelochelys cantoni Gray 1864 \\
\hline
\end{tabular}

Keterangan/Remarks: ") Iskandar, 2000; ") ATTWG 2000, 2007; ") Species 2000; Catalogue of Life: Annual checklist 2006, 2007

Iskandar (2000) mengatakan bahwa di Sumatera terdapat 4 spesies, yaitu $A$. cartilaginea, $D$. subplana, $P$. cantorii, dan Chitra chitra. Selama penelitian ini tidak didapatkan C. chitra. Hasil wawancara selama penelitian pun tidak didapatkan informasi mengenai C. chitra di Sumatera Selatan. Keberadaan C. chitra di Sumatera menurut Iskandar (2000) meliputi Nangroe Aceh Darusslam, Sumatera Utara, dan Jambi.

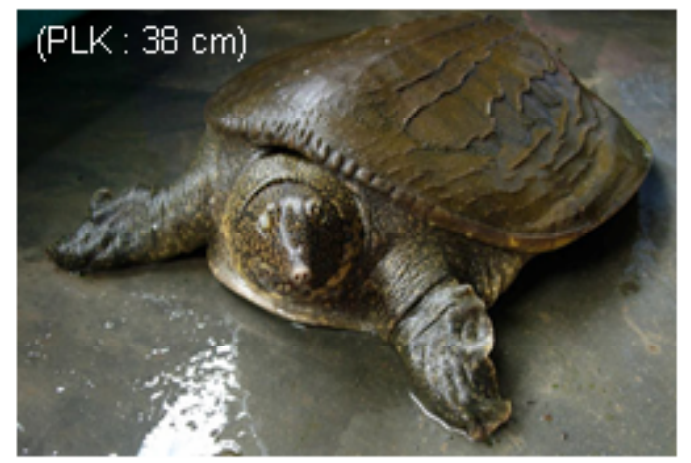

Gambar 4. Labi-labi super (Amyda cartilaginea Boddaert 1770).

Figure 4. Superclass softshell turtle (Amyda cartilaginea Boddaert 1770). 


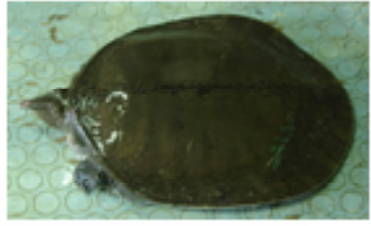

PLK : $13,2 \mathrm{~cm}$

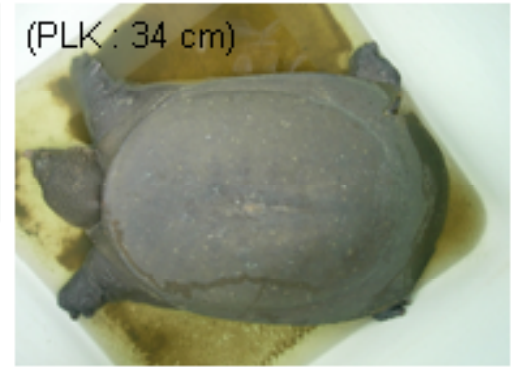

Gambar 5. Figure 5.
Labi-labi batu atau labi-labi curup (Dogania subplana Geoffroy 1809).

Stone or curup shoftshell turtle (Dogania subplana Geoffroy 1809).

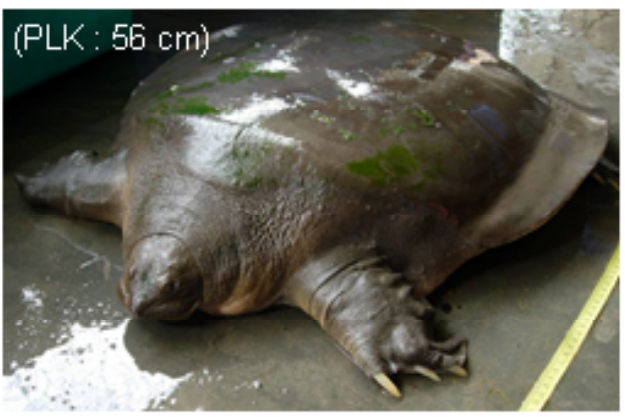

Gambar 6.

Bidari (Pelochelys cantorii Gray 1864).

Figure 6.
Bidari shoftshell turtle (Pelochelys cantorii Gray 1864).
Setiap jenis mempunyai morfologi yang berbeda (Gambar 4, 5, dan 6). Gambar-gambar tersebut memperlihatkan perbedaan morfologi yang sangat mendasar pada setiap jenis yaitu karapas dan kepala.

Perbedaan yang sangat jelas terlihat pada $P$. cantorii dibandingkan dengan 2 jenis lain. Sementara itu, $A$. cartilaginea dan $D$. subplana mempunyai kemiripan pada karapas, plastron, dan kepala. Perbedaan yang sangat mendasar antara $A$. cartilaginea dan $D$. subplana adalah bentuk bagian anterior karapas. Anterior karapas A. cartilaginea terdapat tonjolan menyerupai spiral berjumlah 1 baris, sedang D. subpalana halus (Stuart et al., 2001). Perbedaan ini dapat langsung terlihat baik pada saat berukuran anakan maupun dewasa.

Perbedaan yang lain pada permukaan karapas. Permukaan karapas $A$. cartilaginea terdapat ada gigir longitudinal, sedangkan $D$. subplana halus. Keberadaan gigir longitudinal pada $A$. cartilaginea tersebut didukung dari hasil penelitian Kasmiruddin et al. (1999). Ernest \& Barbour (1987) mengatakan bahwa gigir longitudinal pada permukaan karapas $A$. cartilaginea hanya terlihat pada $A$. cartilaginea muda karena akan menghilang pada saat dewasa. Pola warna kepala pada individu muda juga dapat dijadikan variabel identifikasi. Pola warna kepala $A$. cartilaginea berupa bintik-bintik kuning atau putih, sedangkan $D$. subplana berupa alur garis hitam memanjang (Stuart et al., 2001) seperti alur warna pada buah semangka. Identifikasi morfologi sangat diperlukan untuk mengetahui secara pasti spesies yang dimanfaatkan dan pemantauan.

Pengukuran panjang lengkung karapas dan lebar lengkung karapas $A$. cartilaginea dan $D$. subplana memperlihat nilai perbandingan yaitu lebar lengkung karapas $A$. cartilaginea $0,89 \pm 0,05$ dari panjang lengkung karapas dan lebar lengkung karapas $D$. subplana $0,75 \pm 0,02$ dari panjang lengkung karapas (Tabel 2). Hal tersebut, membuktikan bahwa bentuk karapas $A$. cartilaginea lebih bundar daripada $D$. subplana pada panjang lengkung karapas antara 13 sampai dengan $35 \mathrm{~cm}$. Analisis tersebut juga didukung dari analisis $t_{\text {test }}$ dengan jumlah contoh yang beda, sehingga didapatkan bahwa terdapat perbedaan yang signifikan antara $A$. cartilaginea dan $D$. subplana dengan panjang lengkung karapas $(\mathrm{t}=2,332 ; \mathrm{df}=73$; $P<0,05)$ dan lebar lengkung karapas $(t=3,470 ; d f=73$; $P<0,05)$.

Data log book yang dimulai dari pertengahan bulan April 2006 sampai dengan Pebruari 2007, selain menggambarkan jenis juga memperlihatkan jumlah yang tertangkap dari setiap jenis. Data tersebut memperlihatkan bahwa $A$. cartilaginea merupakan jenis yang mendominasi tangkapan dengan frekuensi $84,28 \%$, yang diikuti oleh $D$. subplana dan $P$. cantorii, masing-masing 15,31 dan 0,42\% (Gambar 7). 
Tabel2 Rasio panjang lengkung karapas dan lebar lengkung karapas pada $A$. cartilaginea dan $D$. subplana

Table 2. $\quad$ Ratios of curve median carapace for length width of $\boldsymbol{A}$. cartilaginea and $\boldsymbol{D}$. subplana

\begin{tabular}{|c|c|c|c|c|c|}
\hline \multicolumn{3}{|c|}{ Amyda cartilaginea } & \multicolumn{3}{|c|}{ Dogania subplana } \\
\hline \multicolumn{2}{|c|}{ Kaparas } & \multicolumn{4}{|c|}{ Kaparas } \\
\hline PLK (cm) & LLK (cm) & Rasio (P:L) & PLK (cm) & LLK (cm) & Rasio (P:L) \\
\hline 13,1 & 12 & 0,92 & 13,2 & 9,7 & 0,73 \\
\hline 16,5 & 14,8 & 0,90 & 16,5 & 12,6 & 0,76 \\
\hline 17 & 14,1 & 0,83 & 17,1 & 13,1 & 0,77 \\
\hline 17,9 & 16 & 0,89 & 18 & 12,8 & 0,71 \\
\hline 18,8 & 17,7 & 0,94 & 19,4 & 14,8 & 0,76 \\
\hline 21 & 18,2 & 0,87 & 19,9 & 15,2 & 0,76 \\
\hline 21 & 19,6 & 0,93 & 20,5 & 15,1 & 0,74 \\
\hline \multirow[t]{2}{*}{34,6} & 28,1 & 0,81 & 34,5 & 27,2 & 0,79 \\
\hline & & 7,09 & & & 6,03 \\
\hline Nilai rata-rata rasio & & 0,89 & & & 0,75 \\
\hline Standar daviasi rasi & & 0,05 & & & 0,02 \\
\hline Persamaan linier & & $=0,7523 x+2,525$ & & & $y=0,8217 x-1,2797$ \\
\hline
\end{tabular}

Dominansi tangkapan $A$. cartilaginea kemungkinan besar dipengaruhi lebar rentang habitat jenis itu yang terlihat dari beberapa karakter biologi pendukung dibandingkan 2 jenis lain (Tabel 3 ).

Sumatera Selatan terbagi dalam 14 wilayah administrasi kabupaten dan kota (Badan Pemerintah Daerah Sumatera Selatan, 2005). Berdasarkan pada pembagian tersebut, maka ibukota dari kabupaten dan kota digunakan sebagai titik distribusi
Trionychidae di Sumatera Selatan. Wilayah Sumatera Selatan yang luas tersebut terdiri atas beberapa satuan wilayah pengelolaan daerah aliran sungai yang terbagi dalam setiap kabupaten dan kota. Luas daerah aliran sungai di Sumatera Selatan meliputi 93,05\% dari wilayah Sumatera Selatan yang berpotensi sebagai habitat labi-labi. Persentase luasan tersebut berdasarkan pada perbandingan antara luas wilayah daratan dengan satuan wilayah pengelolaan daerah aliran sungai di Sumatera Selatan.

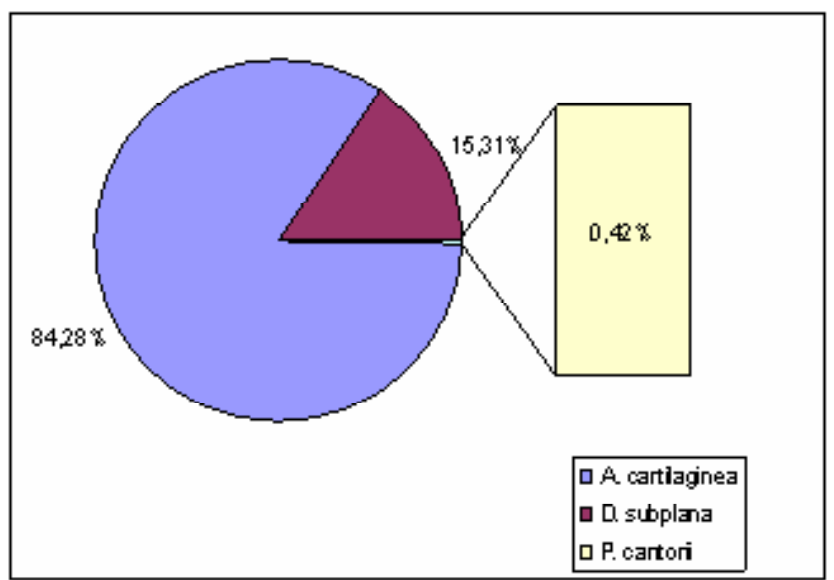

Gambar 7. Persentase jenis labi-labi yang tertangkap dari pertengahan bulan April 2006 sampai dengan Pebruari 2007.

Figure 7. Persentage of softshell turtles caught in April 2006 to February 2007.

Berdasarkan pada hasil wawancara dan pengisian log book diketahui daerah distribusi 3 jenis tersebut di Sumatera Selatan yang meliputi 12 wilayah kabupaten atau kota. Akan tetapi, ke-3 jenis tersebut tidak dijumpai pada semua lokasi di Sumatera Selatan (Gambar 8).
Jenis yang terlihat jelas mempunyai daerah distribusi yang merata di Sumatera Selatan dan mendominasi dari jenis yang ada ditunjukkan dengan jumlah tangkapan adalah A. cartilaginea (Gambar 9). Ernst \& Barbour (1987) mengatakan bahwa habitat A. cartilaginea meliputi perairan dataran tinggi sampai 
dengan dataran rendah. Contoh $A$. cartilaginea dari penelitian yang telah dilakukan oleh Kasmiruddin et al. (1999) didapatkan dari Sungai Musi dan Sungai Lematang, yang melalui beberapa kabupaten di Sumatera Selatan (Lampiran 2). Hal tersebut, memperkuat bukti daerah distribusi $A$. cartilaginea di Sumatera Selatan. Koleksi Museum Zoologicum Bogoriensis, Pusat Penelitian Biologi-Lembaga IImu Pengetahuan Indonesia (kode MZB. Test. 0014, MZB.
Test. 0015, dan MZB. Test. 0016) mencatat bahwa A. cartilaginea ditemukan dari perairan pada ketinggian $350 \mathrm{~m}$ dpl. Iskandar (2000) juga mengatakan bahwa habitat yang paling disukai $A$. cartilaginea adalah perairan berdasar lumpur dan berarus lambat. Tipe perairan tersebut banyak terdapat di dataran rendah yang meliputi sungai, rawa, dan danau sungai mati (oxbow).

Tabel 3. Beberapa informasi biologi jenis A. cartilaginea, D. subplana, dan $P$. cantorii Table 3. $\quad$ Some biological information of $\boldsymbol{A}$. cartilaginea, $\boldsymbol{D}$. subplana, and $\boldsymbol{P}$. cantorii

\begin{tabular}{|c|c|c|c|c|}
\hline Jenis/Species & Habitat/Habitats & $\begin{array}{l}\text { Jumlah telur (but ir } \\
\text { atau sarang)! } \\
\text { Egg numbers or } \\
\text { nests }\end{array}$ & $\begin{array}{l}\text { Ukuran teluri } \\
\text { Egg sizes } \\
\text { (mm) }\end{array}$ & $\begin{array}{l}\text { Waktu bertelur (kali } \\
\text { per tahun)/ } \\
\text { Nesting time (per } \\
\text { year) }\end{array}$ \\
\hline A. cartilaginea & $\begin{array}{l}\text { Perairan berans lambat } \\
\text { (sungai, kolam, rawa); } \\
\text { Perairan dataran tinggi sampai } \\
\text { dataran rendah }\end{array}$ & 40 & $\begin{array}{c}36^{*} \\
\text { (2 butir) }\end{array}$ & 4 \\
\hline D. subpiana & $\begin{array}{l}\text { Sungai kecil dalam hutan; } \\
\text { Sungai kecil berair jernih di } \\
\text { dataran tinggi (hill stream) }\end{array}$ & $=10$ & $\begin{array}{c}30^{*} \\
\text { (1 butir) }\end{array}$ & $2-3$ \\
\hline P. cantorii & $\begin{array}{l}\text { Muara sungai besar; } \\
\text { Perairan dataran rendah }\end{array}$ & $20-30$ & $30-35$ & - \\
\hline
\end{tabular}

Keterangan/Remarks: ${ }^{*}=$ pengukuran langsung (direct measurement)

Sumber/Sources: Ernst \& Barbour (1987); Iskandar (2000)

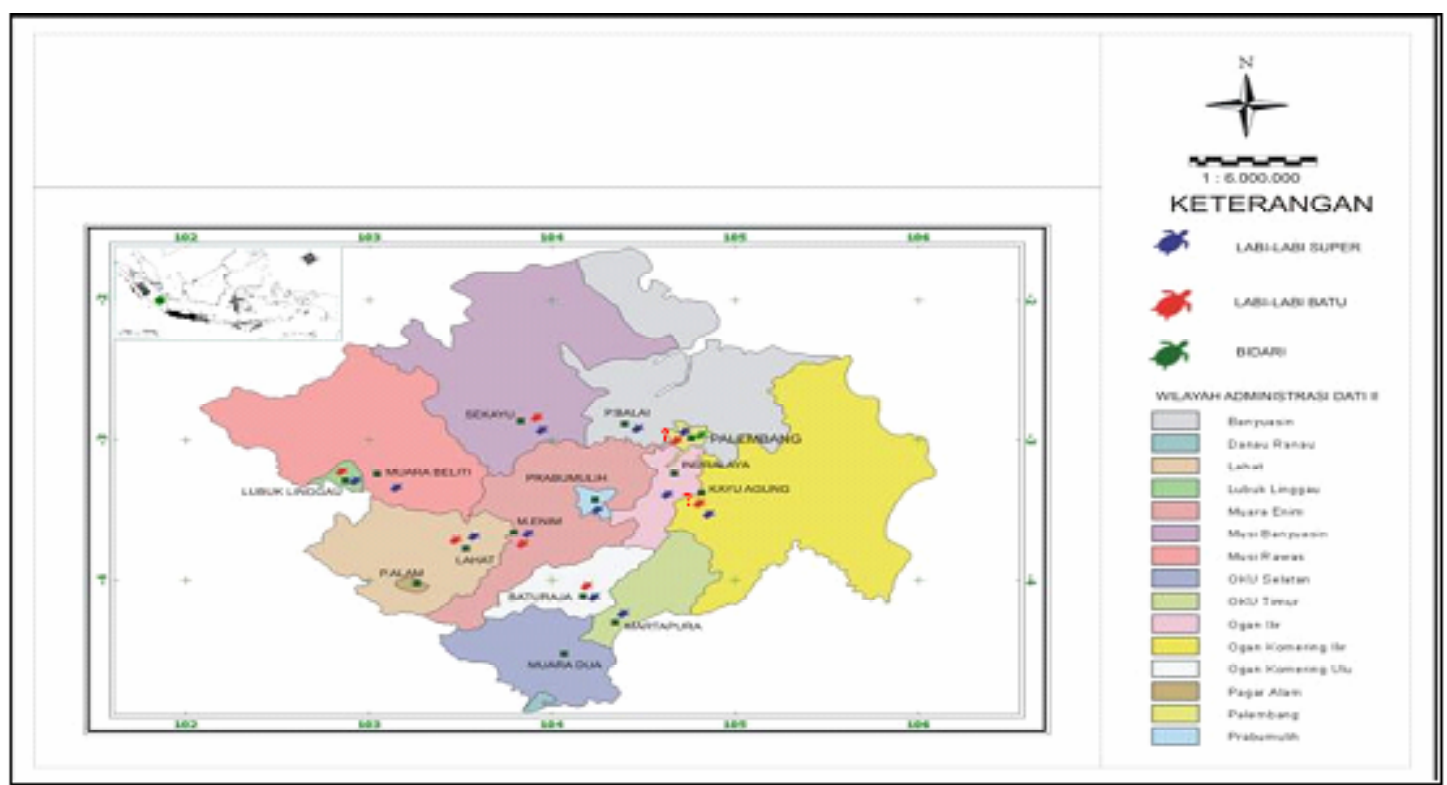

Gambar 8. Peta distribusi labi-labi super (A. cartilaginea), labi-labi batu atau curup (D. subplana), dan bidari ( $P$. cantorii) di Sumatera Selatan.

Figure 8. $\quad$ Distribution map of super class shoftshell turtle (A. cartilaginea), stone or curup (D. subplana), and bidari (P. cantorii) in South Sumatera. 


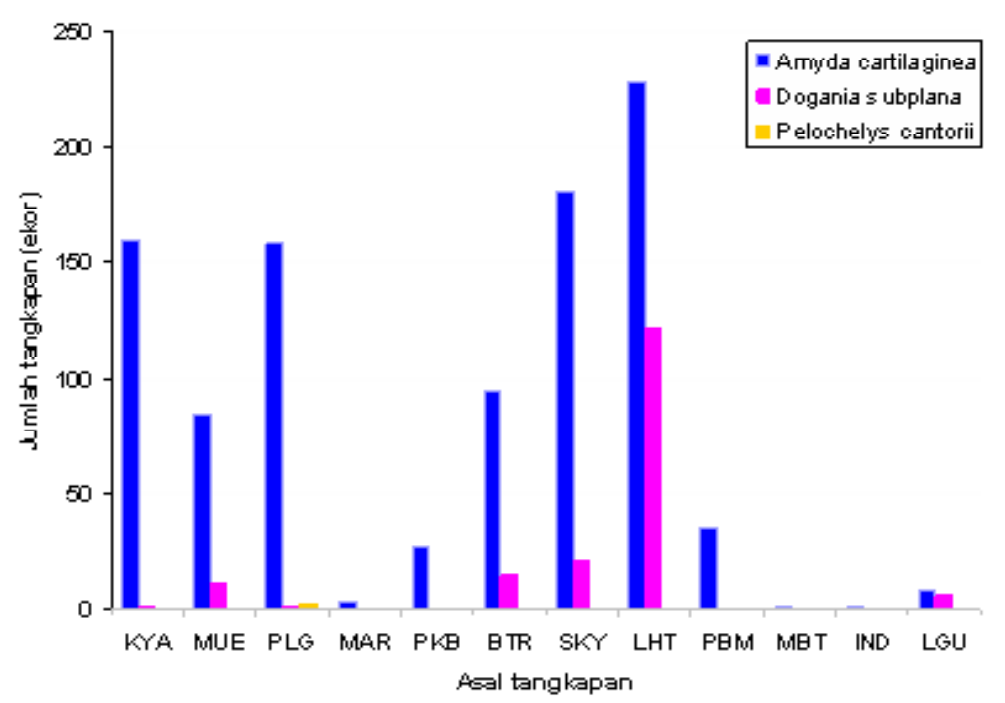
Keterangan/Remarks: $\mathrm{KYA}=$ Kayu Agung; $\mathrm{MUE}=$ Muara Enim; $\mathrm{PLG}=$ Palembang; $\mathrm{MAR}=$ Martapura $\mathrm{PKB}=\mathrm{Pangkalan}$ Balai; BTR = Baturaja; LHT = Lahat; SKY = Sekayu; PBM = Prabumulih; MBT = Muara Beliti; IND $=$ Indralaya; $\mathrm{LGU}=$ Lubuk Linggau

Gambar 9 . Volume jenis berdasarkan pada lokasi tangkap.

Figure 9. The volume of softshell turtles in catch location.

Ketinggian lokasi tangkap A. cartilaginea tertinggi adalah Kabupaten Lubuk Linggau (141 m dpl), sedangkan yang terendah adalah Kotamadya Palembang (7 m dpl). Oleh karena itu, dapat dipastikan bahwa topografi Sumatera Selatan sebagian besar merupakan habitat $A$. cartilaginea (Gambar 10). Keadaan tersebut juga ditunjang oleh luas perairan umum daratan daerah aliran sungai yang meliputi 93,05\% dari luas Sumatera Selatan yang di dalam termasuk juga rawa. Topografi wilayah Sumatera Selatan dengan $25 \%$ daerah rawa mempunyai ciri berarus lambat dan terdapat sungaisungai kecil berarus lambat merupakan habitat $A$. cartilaginea.
Sementara itu, jenis seperti $D$. sublana terlihat hanya dijumpai di daerah pegunungan, meskipun ada data yang mencatat berasal dari Palembang dan Ogan Komering llir yang berjumlah masing-masing 1 ekor. $\mathrm{Hal}$ tersebut, sesuai dengan hasil penelitian Kasmiruddin (2000) di Propinsi Bengkulu di mana $D$. subplana lebih banyak dijumpai karena Bengkulu memiliki habitat yang lebih sesuai untuk $D$. suplana dibandingkan $A$. cartilaginea karena wilayah tersebut memiliki topografi yang didominasi oleh daerah pegunungan. Penyebaran P. cantorii tidak terlalu jelas karena jumlah contoh yang diperoleh sangat sedikit. Data log book dan wawancara diketahui secara pasti bahwa P. cantorii berasal dari Palembang tepat di hilir Sungai Musi (Gambar 11). 


\section{Gambar 10.}

Figure 10.

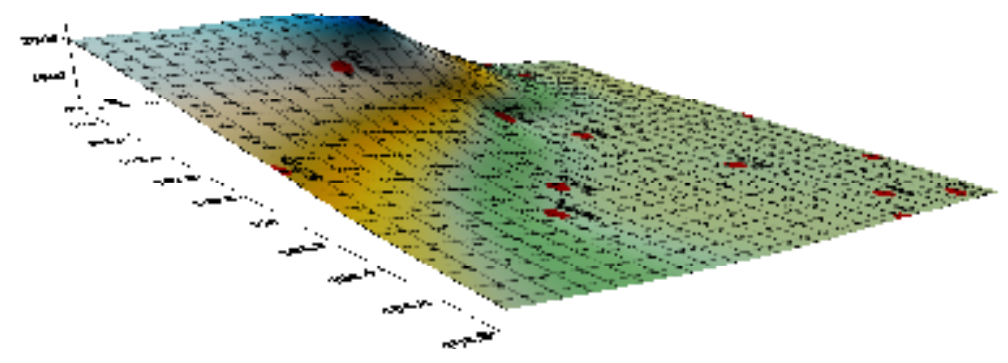

Keterangan (Finarks):

GUD = Gunung Dempo (2630 $\mathrm{m} \mathrm{dpl})$

GUP = Gunung Patah $(1597 \mathrm{~m} \mathrm{dpl})$

GUS = Gunung Seminung (1051 m dpl)

(Sumber data: Badan Pusat Statistik

Kabupaten dan

Kota 2006; Badan

Perencanaan Pembangunan DaerahBa

ppeda Sumatera s Selatan 2005)

KYA = Kayu Agung; MUUE = Muara Enim;

PLG = Palembang; MAR = Martapura;

PKB = Pangkalan Balai; BTR = Baturaja;

LHT = Lahat: $S K Y=$ Sekaru:

PBM = Prabumulih; MBT = Mu ara Beliti;

IND = Indralaya; LGU = Lubuk Linggau

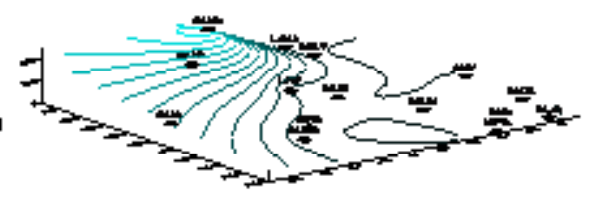

(1)

Topografi Propinsi Sumatera Selatan tergambar dalam gradasi warna berdasarkan pada ketinggian (GUD = Gunung Dempo (biru)) dan ketinggian beberapa ibukota kabupaten yang merupakan daerah penangkapan labi-labi ( $A$. cartilaginea, $D$. subplana, dan $P$. cantorii). South Sumatera tophography in colour degradation altitude (GUD = Gunung Dempo (blue)) and altitude of catch location of softshell turtles (A. cartilaginea, D. subplana, and $\boldsymbol{P}$. cantorii).

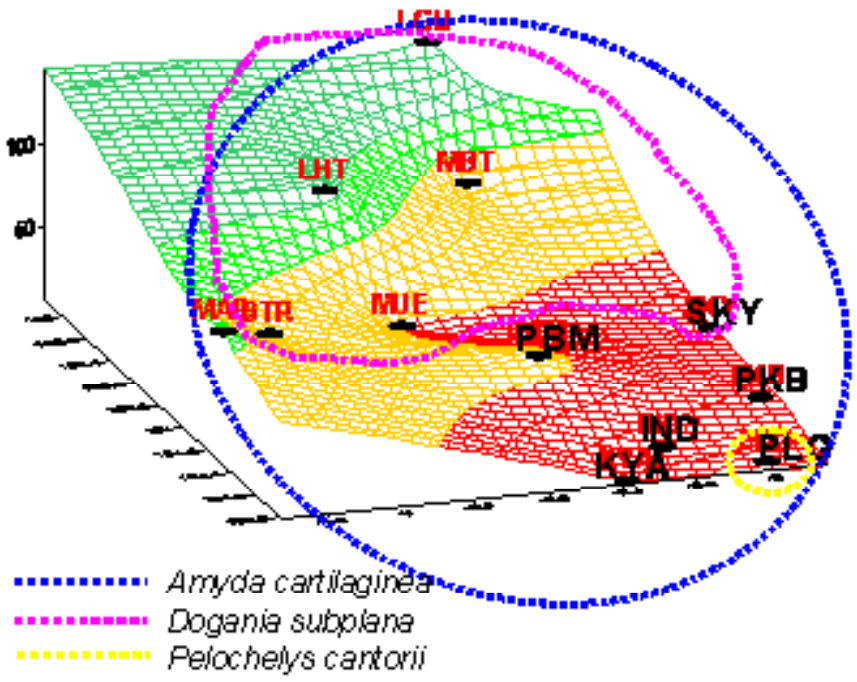

Keterangan/Remarks:KYA = Kayu Agung; $\mathrm{MUE}=$ Muara Enim; $\mathrm{PLG}=$ Palembang; $\mathrm{MAR}=$ Martapura; $\mathrm{PKB}=$ Pangkalan Balai; BTR = Baturaja; LHT = Lahat; SKY = Sekayu; PBM = Prabumulih; $\mathrm{MBT}=$ Muara Beliti; IND = Indralaya; LGU = Lubuk Linggau

Gambar 11. Diagram ven distribusi A. cartiliginea, D. suplana, dan P. cantorii berdasarkan pada data log book yang diplot pada ketinggian tempat.

Figure 11. Vent diagram of A. cartiliginea, D. suplana, and P. cantorii distribution based on log bokk plotted in altitude. 


\section{KESIMPULAN}

1. Ada 3 jenis Trionychidae di Sumatera Selatan yaitu labi-labi super (Amyda cartilaginea Boddaert 1770), labi-labi curup atau labi-labi batu (Dogania subplana Geoffroy 1809), dan bidari (Pelochelys cantorii Gray 1864). Jenis yang paling banyak didapatkan yaitu $A$. cartilaginea.

2. Distribusi Trionychidae meliputi seluruh wilayah Sumatera Selatan. Distribusi $A$. cartilaginea yang paling luas, kemudian diikuti $D$. subplana dan $P$. cantorii.

\section{UCAPAN TERIMA KASIH}

Penulis mengucapkan terima kasih pada para pedagang pengumpul kura-kura air tawar yang ada di Palembang, terutama untuk Bapak Hasan, Bapak Joni, Bapak Ai, dan Bapak Usman, serta semua rekan yang membantu dalam pengukuran dan pencatatan di tempat kerja masing-masing. Ucapan terima kasih juga kepada Tribudi Hikmawan dan Zulkarnaen Fahmi.

\section{PERSANTUNAN}

Kegiatan dari hasil riset inventarisasi mamalia air (pesut), penyu, dan labi-labi, T. A. 2006, di Pusat Riset Perikanan Tangkap, Ancol-Jakarta.

\section{DAFTAR PUSTAKA}

Asian Turtle Trade Working Group. 2000. Amyda cartilaginea. In IUCN 2006. 2006 IUCN Red List of Threatened Species. <http:// www.iucnredlist.org/>. Downloaded on 27 March 2007.

Asian Turtle Trade Working Group. 2000. Dogania subplana. In IUCN 2006. 2006 IUCN Red List of Threatened Species. <http://www.iucnredlist.org/ >. Downloaded on 27 March 2007.

Asian Turtle Trade Working Group. 2000. Pelochelys cantorii. In IUCN 2006. 2006 IUCN Red List of Threatened Species. <http://www.iucnredlist.org/ >. Downloaded on 27 March 2007.

Badan Perencanaan Pembangunan Daerah Sumatera Selatan. 2005. Profil Sumatera Selatan. Badan Perencanaan Pembangunan Daerah Sumatera Selatan. Palembang. vii+77 hlm.
Ernst, C. H. \& R. W. Barbour. 1987. Turtles of the World. The Smithsonian Institution. United States of America. 96-116.

Harless, M. \& H. Morlock. 1979. Turtles: Perspectives research. John Wiley \& Sons Inc. Canada. 92.

Iskandar, D. T. 2000. Kura-kura dan buaya Indonesia, Papua Nugini. PALMedia Citra. Bandung. xix+211 hlm.

Kasmiruddin, N. Sugiri, B. Suryobroto, \& M. F. Rahardjo. 1999. Studi keragaman genetik labi-labi kuning, Amyda cartilaginea (Testudines; Trionychidae) dari Bengkulu dan Palembang. Prosiding Seminar Nasional Konservasi Keanekaragaman Amfibia dan Reptilia di Indonesia. Bogor. 43-7.

Kasmiruddin. 2000. Studi populasi dan ekologi labilabi (Testudines; Trionychidae) di Propinsi Bengkulu. Laporan Penelitian. Fakultas Keguruan dan Ilmu Pendidikan. Universitas Muhammadiyah Bengkulu. Bengkulu: viii $+30 \mathrm{hlm}$. (tidak dipublikasikan).

Oktaviani D., S. Schope, \& M. D. Kusrini. 2006. Kurakura air tawar sebagai komoditas perikanan di Sumatera Selatan. Prosiding Seminar Nasional: Forum Perairan Umum Indonesia III. Palembang. 72-79.

Pough, F. H., R. M. Andrews, J. E. Cadle, M. L. Crump, A. H. Savitzky, \& K. D. Wells. 2004. Herpetology. $3^{\text {rd }}$ edition. Pearson Education. Inc. United State of America. ix+726 hlm.

Pritchard, P. C. H. 1979. Taxonomy, evolution, and zoogeography. Turtles: Perspective and Research. John Wiley \& Sons. Inc. Unites State of America. $1-42$.

Riyanto. A. \& Mumpuni. 2003. Metode survei dan pemantauan populasi satwa: Kura-Kura. Bidang Zoologi. Pusat Penelitian Biologi. Lembaga IImu Pengetahuan Indonesia. Cibinong. v+24 hlm.

Species 2000. Amyda cartilaginea Boddaert. 1770. In Catalogue of life: Annual checklist 2006. http:// www.catalogueoflife.org/. 12 Februari 2007. Pukul $15.00 \mathrm{WIB}$.

Species. 2000. Dogania subplana Geoffroy 1809. In Catalogue of life: Annual checklist 2006. http:// 
www.catalogueoflife.org/. 12 Februari 2007. Pukul 15.05 WIB.

Species 2000. Pelochelys cantorii Gray 1864. In Catalogue of life: Annual checklist 2006. http:// www.catalogueoflife.org/. 12 Februari 2007. Pukul 14.55 WIB.

Stuart, B. L., P. P. van Dijk, \& D. B. Hendrie. 2001. Photographic guide to the turles of Thailand, Laos,
Vietnam, and Cambodia. Wildlife Conservation Society. Cambodia. $84 \mathrm{hlm}$.

van Dijk, P. P. 2000. The status of turtles in Asia. Chelonian Research Monograph. 2. 15-23.

van Heezik, Y. M., J. Cooper, \& P. J. Seddon. 1994. Population characteristics and morphometrics of angulate tortoises on Dessen Island, South Africa. Journal of Herpetology. 28 (4). 447-453. 
Lampiran 1. Tabel isian (log book) pengumpulan data biologi labi-labi

Appendix 1. Log book of biological data collection of shoftshell turtles

Nama Pedagang/Perusahaan

Lokasi

:Palembang, Sumatera Selatan

Komoditas : Jenis labi-labi

\begin{tabular}{|c|c|c|c|c|c|c|c|c|}
\hline \multirow[b]{2}{*}{ No. } & \multirow[b]{2}{*}{ Tanggal } & \multirow[b]{2}{*}{$\begin{array}{l}\text { Lokasi } \\
\text { tangkap }\end{array}$} & \multirow[b]{2}{*}{$\begin{array}{l}\text { Jenis labi-labi } \\
\text { (super/batu/ } \\
\text { bidari/lain-lain) }\end{array}$} & \multicolumn{3}{|c|}{ Ukuran } & \multicolumn{2}{|c|}{ Jenis Kelamin } \\
\hline & & & & $\begin{array}{l}\text { Panjang } \\
\text { tempurung } \\
\text { (cm) }\end{array}$ & $\begin{array}{l}\text { Lebar } \\
\text { tempurung } \\
\text { (cm) }\end{array}$ & $\begin{array}{c}\text { Bobot } \\
\text { (kg) }\end{array}$ & Jantan & Betina \\
\hline
\end{tabular}


Identifikasi dan Distribusi Jenis Labi-Labi (Famili: Trionychidae) di Sumatera Selatan (Oktaviani, D. et al.)

Lampiran 2. Satuan wilayah pengelolaan daerah aliran Sungai Musi berdasarkan pada wilayah administrasi Sumatera Selatan

Appendix 2. Management unit of waters catchment area of Musi Rivers based on administrative province of South Sumatra

\section{WILAYAH KERJA GPDAS MUSI}

\begin{tabular}{|c|c|c|c|}
\hline Kabupaten/Alnmet & DAS & Sub D AS & Luas (Ha) \\
\hline \multicolumn{4}{|l|}{ SWP DAS Musi } \\
\hline 1 Kab. Banyuasin & DASMUSi & Sub DAS Banyuasin & $203,220.28$ \\
\hline Dinas Kehutanan dan Perkebunan & & Sub DAS Kom ering & $8,260.38$ \\
\hline Jl. Merdeka No.3 Pangkalan Balai & & Sub DAS Lem atang & $8,454.54$ \\
\hline \multirow[t]{12}{*}{ T elp.(0711) 891454} & & $\begin{array}{l}\text { Sub DAS Musi Hilir } \\
\text { Sub DAS Ogan }\end{array}$ & $\begin{array}{r}402,640.30 \\
2,899.52\end{array}$ \\
\hline & & Jumlah & $625,475.02$ \\
\hline & DAS Benawang & Sub DAS Benawang DS & $130,060.16$ \\
\hline & & Sub DAS Sembilang & $116,836.29$ \\
\hline & & Jumlah & $246,896.45$ \\
\hline & DAS Banyuasin & Sub DAS Calik & $170,665.80$ \\
\hline & & Sub DAS Lalan & $11,293.55$ \\
\hline & & Jumlah & $181,959.35$ \\
\hline & DAS Bulu R arinding & Sub DAS Lumpur & 495.41 \\
\hline & & Sub DAS Sugihan & $95,918.93$ \\
\hline & & Jumlah & $96,414.34$ \\
\hline & & Jumlah Total & $1,150,745.16$ \\
\hline $2 \mathrm{Kab}$. Lahat & DAS Musi & Sub DAS Beliti & $17,311.75$ \\
\hline Dinas P erk ebunan dan Kehutanan & & Sub DAS Kikim & $151,261.92$ \\
\hline Jl. RE Martadinata No.74 Bandar & & Sub DAS Lem atang & $188,066.71$ \\
\hline Agung, Lahat & & Sub DAS Musi Hulu & $221,000.10$ \\
\hline \multirow[t]{2}{*}{ T elp. (0731) 321523} & & Sub DAS Sem angus & $31,829.52$ \\
\hline & & Jumlah & $609,470.00$ \\
\hline 3 Kab. Muara Enim & DAS Musi & Sub DAS Komering & 754.54 \\
\hline Dinas Kehutanan & & Sub DAS Lem atang & $588,064.88$ \\
\hline Jl. Jend. Bam bang Oetoyo No.23 & & Sub DAS Musi Hilir & 9.81 \\
\hline \multirow[t]{3}{*}{ Telp.(0734) 421081 } & & Sub DAS Ogan & $249,282.43$ \\
\hline & & Sub DAS Sem angus & $12,517.93$ \\
\hline & & Jumlah & $850,629.59$ \\
\hline 4 Kab. Musi Banyuasin & DAS Musi & Sub DAS Batanghari Leko & $297,088.08$ \\
\hline Dinas Kehutanan dan Perkebunan & & Sub DAS Lem atang & $12,064.15$ \\
\hline Jl. Kol. Wahid Udin Lingk. VII & & Sub DAS Musi Hilir & $16,464.31$ \\
\hline No. 245 & & Sub DAS Rawas & $19,717.03$ \\
\hline \multirow[t]{9}{*}{ T elp. (0714) 321202} & & Sub DAS Sem angus & $276,578.16$ \\
\hline & & Jumlah & $621,911.73$ \\
\hline & DAS Benawang & Sub DAS Sembilang & $14,121.78$ \\
\hline & & Sub DAS Benawang DS & $9,184.15$ \\
\hline & & Jumlah & $23,305.93$ \\
\hline & DAS Banyuasin & Sub DAS Calik & $213,408.82$ \\
\hline & & Sub DAS Lalan & $583,117.44$ \\
\hline & & Jumlah & $796,526.26$ \\
\hline & & Jumlah Total & $1,441,743.92$ \\
\hline 5 Kab. Musi Ramas & DAS Musi & Sub DAS Batanghari Leko & $7,869.66$ \\
\hline Dinas Kehutanan & & Sub DAS Beliti & $52,513.89$ \\
\hline Komp.Perkantoran Pemda & & Sub DAS Kikim & $1,548.47$ \\
\hline Jl. Pembangunan, Lubuk Linggau & & Sub DAS Lakitan & $251,564.34$ \\
\hline \multirow[t]{5}{*}{ T elp. (0733) 451142} & & Sub DAS Lem atang & $2,667.48$ \\
\hline & & Sub DAS Musi Hulu & $115,051.55$ \\
\hline & & Sub DAS R awas & $577,078.40$ \\
\hline & & Sub DAS Semangus & $210,790.28$ \\
\hline & & Jumlah & $1,219,084.07$ \\
\hline
\end{tabular}

